\title{
Genetic Variation Analysis of Hevea brasiliensis Genotype Population of In Vitro Micro-Cutting Culture by RAPD Marker
}

\author{
IRFAN MARTIANSYAH ${ }^{*}$, NURHAIMI HARIS ${ }^{1}$, TATI HUSNIYATI ${ }^{2}$, EDY DJAUHARI PURWAKUSUMAH ${ }^{2}$ \\ ${ }^{1}$ Indonesian Research Institute for Biotechnology and Bioindustry, Jl. Taman Kencana No.1, Bogor 16128, Indonesia \\ ${ }^{2}$ Faculty of Math and Science, Bogor Agricultural University, Dramaga, Bogor 16680, Indonesia
}

Diterima 22 Februari 2018/Disetujui 17 Mei 2018

\begin{abstract}
The rubber seeds are insufficient for producing rootstocks to rubber grafting. It can be overcome by an in vitro micro-cutting culture technique developed in the Indonesian Research Institute for Biotechnology and Bioindustry (IRIBB). However, the origin clone of 57 rubber genotypes used as an explant source in vitro micro-cutting culture is not recognized. The study was to investigate the 57 genotypes that came from mixed GT 1, PB 260, and RRIM 600 as parent clones. We investigated using seven primers of Random Amplified Polymorphic DNA (RAPD), i.e., OPA 02, OPA 07, OPA 15, OPB 04, OPC 05, OPC 11, and OPC 20. The qualitative analyzed by electrophoresis $1 \%$ gel agarose. A total of 47 DNA fragments produced with an average of 7 fragments per primer. OPA 02 generated of 13 fragments, whereas OPB 04 only one fragment. The DNA fragment pattern shows the presence of polymorphism. The genetic similarity coefficients obtained in the range of $62-96 \%$. The highest genetic similarity $(96 \%)$ is genotype 70 and 78. It recognized that 42 genotypes from 57 rubber genotypes had the closest relationship with PB 260 clones. Furthermore, six genotypes had a significant growth response as an explant in vitro micro-cutting culture.
\end{abstract}

Key words: DNA, Hevea brasiliensis, Micro-cutting, RAPD, Rubber genotype

\section{INTRODUCTION}

Rubber trees (Hevea brasiliensis) is a vital estate crop that produces natural rubber regarded economic value for Indonesia. The growth of rubber tree plantations in Indonesia, both the area and production leads to grow every year. In 2017, the rubber tree plantation area reached 3.67 million hectares. Meanwhile, natural rubber production increased 2-3\% every year, for instance, from 3.16 million tons in 2016 to 3.23 million tons in 2017 (Kementan 2017). Overall, Indonesia's rubber productivity is relatively low. Several factors are contributing to low productivity, but the principle is the use of planting materials developed by grafting. Grafting is a combination of vegetative and generative (seeds for rootstock). In the Industrial scale, it was initially developed by Van Helten, who established the first two clonal rubber tree plantations in Java and Sumatra (Dijkman 1951). However, the use of rootstock for grafting has limited. It can occur due to several limiting factors such as the seed season is only once a year, the seeds are not drought resistant (recalcitrant) so that they are not durable, and the seeds produced decreased by high latex exploitation (Siagian

*Penulis korespondensi:

E-mail: imartiansyah6311@gmail.com
2012). Moreover, the low maternal fertility in $H$. brasiliensis as a 'monoecious allogamic species' is a barrier that can decrease seed quantities (ClémentDemange et al. 2007). These constraints occurred in the insufficient availability of rubber seeds as a rootstock.

Since 2007, the Indonesian Research Institute for Biotechnology and Bioindustry (IRIBB) conducted intensive research to approach the scarcity of rootstock sources by the in vitro culture technique is called micro-cutting. Micro-cutting is a plant propagation technique based on tissue culture using axillary buds of rubber tree as explants (NurhaimiHaris et al. 2009). The multiplication rate by micro or macro cuttings is low. It is limited by strong apical dominance that regulates the growth of the stems of rubber trees (Granet et al. 2011). However, micro-cutting is a relatively simple technique that uses for propagating of some woody plant species such as rubber trees. Several rejuvenated rubber plant is supposed enough to start the micro-cutting process (Mignon and Werbrouck 2018).

The propagation uses genotypes of rubber tree derived from a mixture of seeds clones GT 1, PB 260, and RRIM 600 (commercial rubber clones) (Siagian 2012). In the beginning, a total of 100 rubber genotypes were selected from seedlings of 43,000 seeds of the three-parent clones in the rootstock nursery field at the Sungei Putih 
Research Institute (North Sumatra). The criteria for seeds selection based on the best growth, such as stem diameter, stem height, and plant growth (Nurhaimi-Haris et al. 2009). Currently, 100 selected genotypes have developed at IRIBB. A total of 57 rubber genotypes can be propagated by the in vitro micro-cutting culture. Several genotypes expected have a great response to the in vitro culture conditions.

However, rubber genotypes are not wellrecognized that origin parent clones due to mixed selection in the field. Hence the origin of rubber clones from several genotypes that respond well in vitro micro-cutting culture is unknown. A total of 57 rubber genotypes were analyzed molecularly to determine their relationship with their parent clones. In the present study, we used molecular markers RAPD (Randomly Amplified Polymorphic DNA). RAPD marker analysis is relevant to the investigation of genetic linkage and diversity (Nejatzadeh-Barandozi et al. 2012). The study aimed to analyze the origin of rubber genotypes among GT 1, PB 260, and RRIM 600. Moreover, the rubber genotypes that came from the same parent clones expected to have an excellent response to the in vitro culture conditions.

\section{MATERIALS AND METHODS}

Planting Material. Plant materials used for DNA isolation were 57 leaves of rubber genotypes, i.e., $2,3,4,5,6,7,8,911,12,13,14,15,17,22$, $23,25,26,27,28,29,30,34,36,37,38,39,40,43$, $44,46,47,48,49,51,52,53,55,56,58,59,60,66$, $68,69,70,72,75,77,78,79,80,83,85,86,88,91$, and three parent clones (GT 1, PB 260, RRIM 600).

Rubber Leaves DNA Isolation (OrozcoCastillo et al. 1994). DNA was isolated from rubber leaves using the Orozco-Castillo et al. (1994) modified. A total of $200 \mathrm{mg}$ samples were ground with the liquid nitrogen (N2), and 5 mg PVP then homogenized with $1 \mathrm{ml}$ extraction buffer. The samples were then transferred into a $2 \mathrm{ml}$ centrifuge tube and incubated at $65^{\circ} \mathrm{C}$ for 30 minutes in the water bath. A total of $750 \mu \mathrm{l}$ chloroform:isoamyl alcohol (24:1) was added and centrifuged at 11,000 rpm for 10 minutes (twice). The supernatant transferred to a new tube added 1 $\mathrm{ml}$ of cold isopropanol. The solution incubated in the refrigerator $\left(4^{\circ} \mathrm{C}\right)$ for 10 minutes. The samples dissolved with TE buffer, $1 / 10$ volume of NaAcetate $3 \mathrm{M} \mathrm{pH} 5.2$ and 2.5 volumes of absolute cold alcohol and then incubated in a freezer $\left(-20^{\circ} \mathrm{C}\right)$ for 30 minutes. Next, the solution centrifuged at 14,000 rpm for 10 minutes. The supernatant removed while the pellet is washed using $70 \%$ alcohol and dried.
The dried DNA pellets dissolved with a 100-500 $\mathrm{ml} \mathrm{TE}$ buffer. The DNA solution was kept in $-20^{\circ} \mathrm{C}$ freezer before PCR analysis.

DNA Qualitative and Quantitative Analysis (Sambrook and Russel 1989). A total of $300 \mathrm{mg}$ agarose dissolved in $30 \mathrm{ml}$ of $1 \mathrm{X}$ TAE solution, to become $1 \%$ gel agarose. Then added $1.5 \mu \mathrm{EtBr}$ and poured into an electrophoresis gel template until the gel solidified. The solid gel transferred to an electrophoresis bath containing TAE $1 \mathrm{X}$. The sample to be electrophoresed with a ratio of $5: 1$ (DNA:loading dye) then injected into the agarose gel well. The marker used was $1 \mathrm{~kb}$ of DNA ladder as much as $0.8 \mu \mathrm{l}$. Electrophoresis results observed with UV lamps in the transilluminator. The analysis was carried out by the spectrophotometric method. The DNA stock solution took as much as $10 \mu \mathrm{l}$ then dissolved with distilled water until the volume reached $750 \mu \mathrm{l}$. Absorbance (A) estimated at wavelengths $260 \mathrm{~nm}$ and $280 \mathrm{~nm}$. The comparison value A260/A280 determines the level of DNA purity.

RAPD (Williams et al. 1990). The PCR master mix made by mixing $0.5 \mu \mathrm{dNTPs} 10 \mathrm{~mm}, 1 \mu \mathrm{l}$ primer, $0.2 \mu 1$ Taq polymerase, $2 \mu$ DNA sample, $2.5 \mu \mathrm{l}$ buffers containing $\mathrm{MgCl}_{2}$, and $18.8 \mu \mathrm{ld}$ water. The amplification process carried out in 45 cycles with the reaction: pre-denaturation $94^{\circ} \mathrm{C}$ for 1 minute, denaturation $94^{\circ} \mathrm{C}$ for 1 minute, annealing $36^{\circ} \mathrm{C}$ for 1 minute, extension $72^{\circ} \mathrm{C}$ for 2 minutes, and finally post-extension $72^{\circ} \mathrm{C}$ for 4 minutes. The amplification results interpreted by using $1.4 \%$ agarose gel. A total of $0.42 \mathrm{~g}$ agarose dissolved with $30 \mathrm{ml}$ TAE buffer $1 \mathrm{x}$, later the electrophoresis process is running at 60 volts for one hour. The results were observed with the UV lamps in the transilluminator and captured using gel documentation.

Data Analysis. The DNA fragment pattern that appears on the gel translated into binary data with manual scoring. Each band represents one character and is given a value based on the presence (' 1 ') or absence (' 0 ') of a band. The binary data is processed into phylogenetic trees using the NTSYS (Numerical Taxonomy and Multivariate Analysis System) program with the UPGMA (Unweight Pair Grouping Method with Arithmetic Averaging) method to reveal the phenotypic descriptions of genetic relationships by similarity coefficients (Rohlf and Slice 1993).

\section{RESULTS}

Integrity and Purity of DNA. The qualitative results on 60 DNAs (57 rubber genotypes and three parent clones) interpreted by using $1.4 \%$ agarose 
gel. The electropherogram shows qualitative results from DNA isolation, which can see from DNA fragments that appear on the gel (Figure 1).

The DNA purity and concentration were measured by spectrophotometry at wavelengths of $260 \mathrm{~nm}$ and $280 \mathrm{~nm}$ - the purity obtained from the ratio of absorbance $260 \mathrm{~nm}$ and $280 \mathrm{~nm}$. The DNA purity obtained ranges from $0.25-2.76$. The results showed that a total of 13 rubber tree genotypes (number 2 , $3,4,5,7,27,30,44,59,60,66,68$, and 85) had a purity value of $1.8-2.0$, which showed that the DNA isolated process had achieved well. However, several genotypes i.e. number $9,12,13,14,15,25$, $28,29,53,70,78,79$, and 86 had values over 2.0. The DNA concentration ranged from 71.25-1766.25 $\mu \mathrm{g} / \mathrm{ml}$. The highest concentration was obtained in genotype 4 , while the lowest in genotype 47 , but it has a moderately high concentration quantitatively. The DNA can continue toward the PCR-RAPD process.

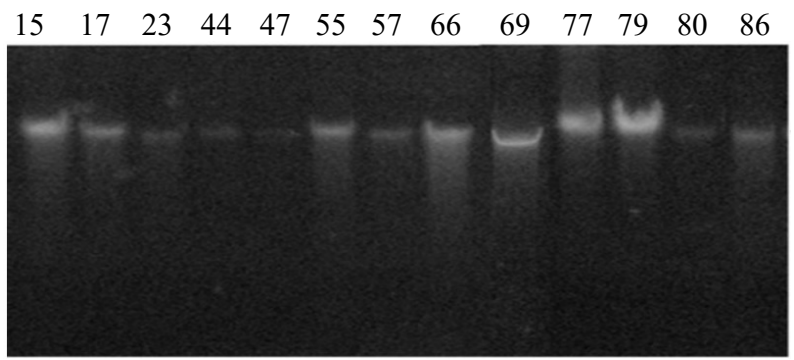

Figure 1. Electropherogram of DNA tested on several rubber genotypes

DNA Fragments with Seven RAPD Primers. The results show that a total of 47 visible fragments were generated. Each primer produces 1-13 fragments with an average were six fragments per primer (Table 1). The fragment size ranges from 500-5000 bp.

DNA fragments were mostly generated by OPA 02 primer as many as 13 DNA fragments, while at least one fragments by OPB 04 primer. The OPA 05 primer offered seven DNA fragments with adequately electropherogram results so that it can clearly distinguish DNA fragment patterns between the tested rubber genotypes (Figure 2).

Phylogenetic Analysis. Based on phylogenetic trees, the population of rubber trees is divided into two major groups at $62 \%$ genetic similarity. The first group consisted of 56 genotypes, while the second group was only one. Moreover, the large group separated into two groups with a higher

Table 1. The number of DNA fragments resulting by seven RAPD primers

\begin{tabular}{lcc}
\hline Primer & Sequences & DNA fragment \\
\hline OPA02 & 5' TGCCGAGCTG 3' & 13 \\
OPA07 & 5' GAAACGCGTG 3' & 9 \\
OPA15 & 5' TTCCGAACCC 3', & 6 \\
OPB04 & 5' GGACTGGAGT 3' & 1 \\
OPC05 & 5' GATGACCGCC3', & 7 \\
OPC11 & 5' AAAGCTGCGG 3' & 3 \\
OPC20 & 5' ACTTCGCCAC 3', & 8 \\
\hline Total & & 47 \\
\hline
\end{tabular}
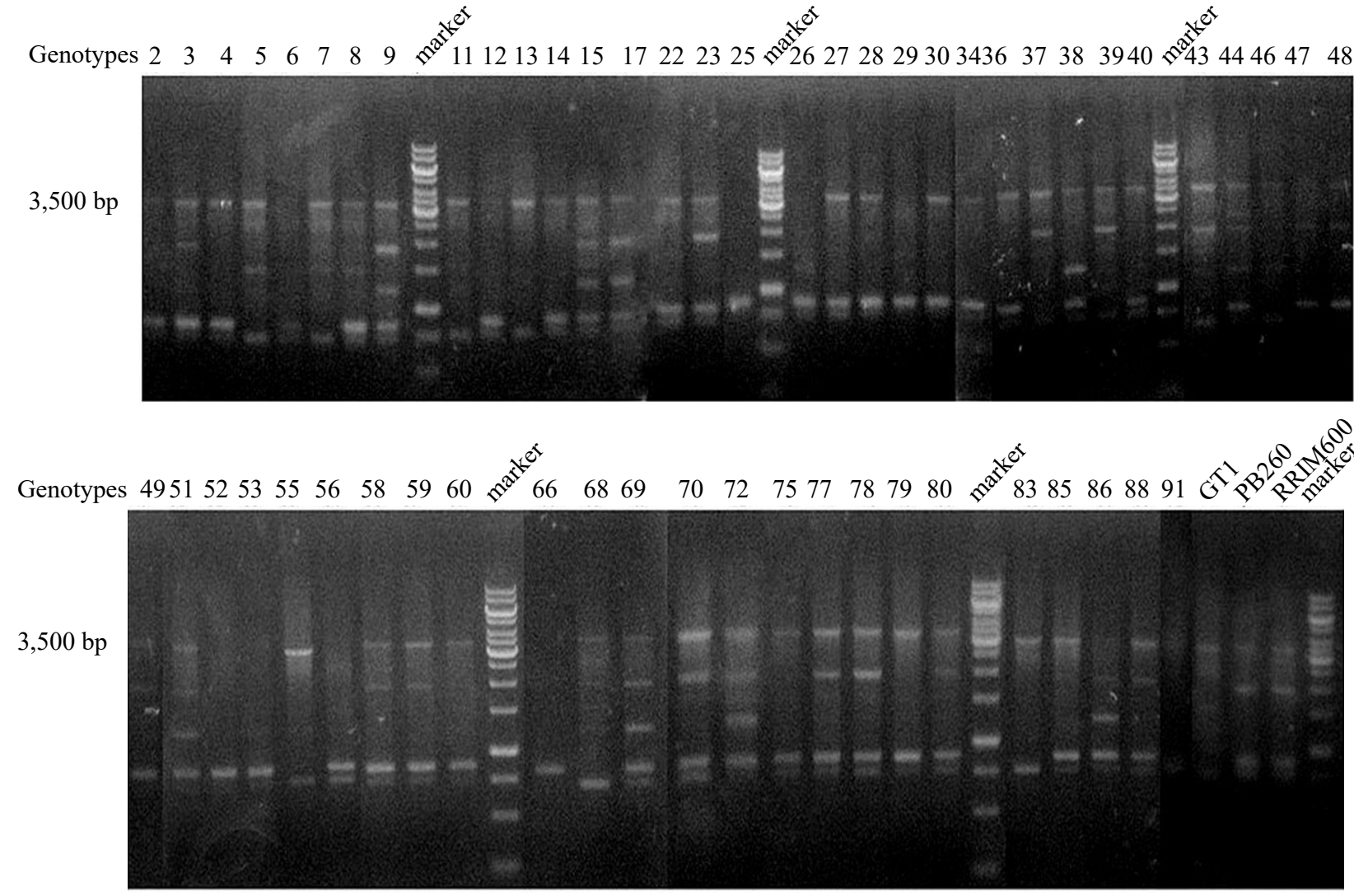

Figure 2. Electropherogram of sixties DNA rubber amplicon by OPC 05 primer 
genetic similarity, which is $67 \%$. The first subgroup consisted of 53 individuals i.e. 2, 3, 4, 5, 6, 7, 8, 9 $11,12,13,14,15,17,22,23,25,27,28,30,34,36$, $37,38,39,40,43,44,46,47,48,49,51,52,53$, $55,56,58,59,60,66,68,69,70,72,75,77,78$, $79,80,83,85,86,88$, PB 260, and RRIM 600. The second subgroup consisted of 3 individuals with genotypes number 26, 29, and 91. Another large group separated from the others that have only one individual, namely GT 1 , which is one of the threeparent clones.

Further grouping considered with higher coefficients of genetic similarity (Figure 3). The first line shows that the $70 \%$ genetic similarity coefficient separates into two broad groups that produce only one individual, which is the first group divided into two subgroups. The second line shows $80 \%$ genetic similarity, which can separate the population into 16 groups. The third line shows a genetic similarity of $90 \%$, which can separate the population into 51 groups that are further divided into more specific groups so that one group has only two individuals that are close together (Figure 3). The genetic similarity values ranged from $60-96 \%$. Most of them are in the range above $65 \%$ and barely are below. The highest genetic similarity (96\%) observed among genotype 70 and 78 . The value of genetic similarity within parent clones is between GT 1 and PB 260 by $64 \%$, GT 1 and RRIM 600 by $66 \%$, and PB 260 and RRIM 600 by $89 \%$.

The genetic similarity value in the matrix shows the kinship of each rubber tree genotype with its three-parent clones. Most of the genotypes tested had the closest relationship with PB 260 clone

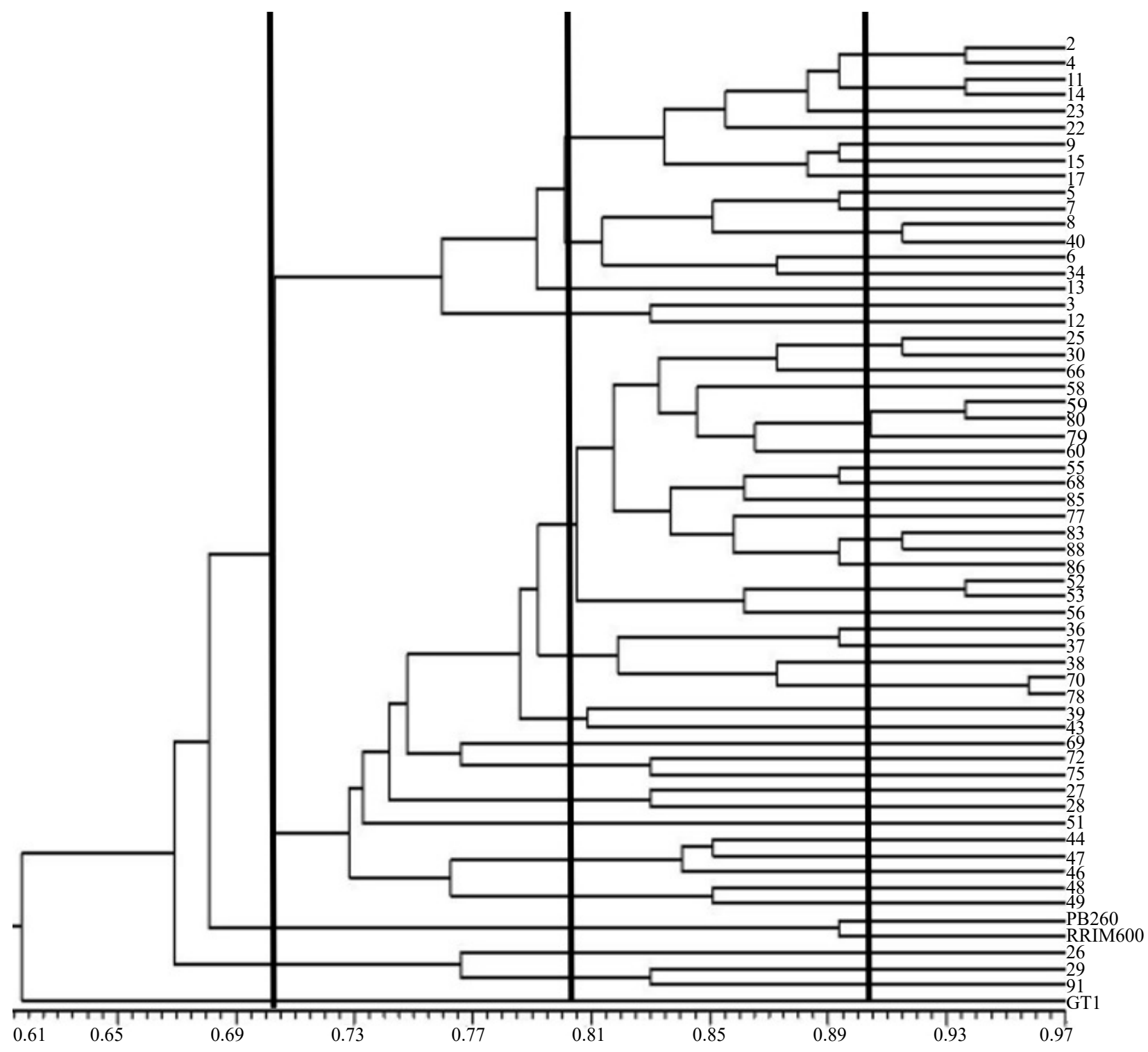

Figure 3. Phylogenetic of 57 rubber genotypes and three parent clones 
such as $2,3,4,5,6,7,8,9,11,13,14,17,22,25$, $26,28,30,34,37,38,39,40,46,49,51,52,53$, $55,56,58,59,60,66,68,69,70,72,75,77,78$, 79,80 , and 86 . While genotype numbers 12,15 , $23,27,43,48,83,88,91$ have the closest kinship relationship with RRIM 600, and genotype 44, 47, 85 with GT 1 clone. Genotypes 29 and 36 have identical genetic similarities with GT 1 and RRIM 600 clones, respectively. It supposed due to a few DNA fragments obtained so that further analysis is needed by adding the number of primers or using molecular markers that are more specific in conducting kinship analysis. Based on the genetic similarity matrix, it identified that a total of 6 out of 10 genotypes have the closest kinship relationship with PB 260 clones are 2, 4, 7, 25, 26, and 78 .

\section{DISCUSSION}

The DNA fragments showed that DNA is not degraded or smear, so it is suitable for use in RAPD analysis. Smears can be affected by the DNA over volume or high voltage during electrophoresed (Ausubel et al. 1999). Several rubber tree genotypes had a purity value of 1.8-2.0, which showed that the DNA isolated process had achieved well. However, another genotype had values over 2.0. It supposed to confirm the presence of RNA contamination. The RNA can be removed by adding RNase during DNA isolation. Other genotypes have DNA purity values below 1.8. It shows protein contaminants. The protein can remove by adding proteinase $\mathrm{K}$. According to Wilson et al. (2000), the high quality of DNA purity value ranging from 1.8-2.0 in the ratio of A260/A280. The value over 2.0 indicates that the sample contains RNA contaminants, while less than 1.8 contains protein contaminants (Yuwono 2006). Purwanto et al. (2002) stated that the success of RAPD techniques determined by DNA template purity and integrity. Poor quality of DNA samples interfere with the primer attaching to the site and inhibit the activity of the DNA polymerase enzyme. This enzyme acts to polymerize DNA, whereas the DNA template that has much fragmentation can eliminate the primary attachment site.

The highest DNA concentration was obtained in genotype 4, while the lowest in genotype 47 , but it has a moderately high concentration quantitatively. The DNA can continue toward the PCR-RAPD process. The process only needs $50 \mu \mathrm{g} / \mathrm{ml}$ of the DNA sample by considering the dilution factor. DNA concentration influences the amplification quality of DNA fragments. The concentrations that are too low can generate thin fragments or even not visually visible, whereas the high concentration causes the fragments to seem thick so that it is hard to differentiate between one fragment and another (Nurhaimi-Haris et al. 2003).

All of the DNA samples amplified using seven RAPD primers, such as OPA 02, OPA 07, OPA
15, OPB 04, OPC 05, OPC 11, and OPC 20. The results show that a total of 47 visible fragments were generated. The average was six fragments per primer. Previous studies using RAPD on 79 rubber tree clones resulted in 5-11 DNA fragments (Nurhaimi-Haris et al. 1998). According to Demeke and Adams (1994), DNA amplification with random primers in RAPD analysis results typically in 5-20 fragments for each primer. The fragments number resulting from amplification by RAPD markers implies indeed lower than the results of AFLP (Nurhaimi-Haris et al. 2003). The DNA fragments pattern that was generated by RAPD shows the presence of polymorphism. Each primer produces various DNA fragments. The DNA fragment polymorphism could be influenced by the numerous variations of individuals in a population. That polymorphism mainly detected as a DNA segment that amplifies one parent but not another, is inherited by Mendelian, and can be used to construct genetic maps in various species (Williams et al. 1990).

In this study, the RAPD marker analysis has succeeded in matching 57 rubber genotypes with the parent clones about $62 \%$ genetic similarity. This value is lower than the previous RAPD study carried out on 79 commercial rubber clones, which is $70 \%$ (Nurhaimi-Haris et al. 1998). NurhaimiHaris et al. (1998) stated that the genetic similarity coefficient between GT 1 and PB 260 was $75 \%$, GT 1 and RRIM 600 by $73 \%$, and PB 260 and RRIM 600 by $82 \%$. Based on phylogenetic trees, the population of rubber trees is divided into two major groups. The three lines in the phylogenetic tree is a variety in grouping individuals. The first line separates into two broad groups, which is the first group divided into two subgroups. It has not produced a branch with a single individual except the sixteenth number branch. An individual in a population that exists in the same kinship group indicates it has a close kinship. Kinship relationship is known of the genetic similarity coefficient value. The plant genetic conservation value is essential to the development of genetic diversity. Genetic diversity assessment within the populations applied using various techniques such as RAPD molecular markers relying on a DNA assay (Mondini et al. 2009). Suryanto (2003) states that a genetic diversity study can be carried out through the analysis of DNA electrophoresis results. Genetic variation study by molecular markers can identify single accessions immediately without the environment influence. RAPD markers have been applied for numerous applications in plant molecular genetic research, although these methods have limitations of weak reproducibility and are commonly not associated with gene regions (Sharma et al. 2018).

The genotypes are used as the source of explants multiplication of rubber rootstock by in vitro microcutting. Not all of these genotypes are suitable and respond well to in vitro culture due to plant vigorous 
and microorganism contamination (Martiansyah et al. 2013). Some genotypes that respond well to in vitro culture are genotypes $2,4,7,25,26,29,33$, 63, 78, and 91 (Nurhaimi-Haris et al. 2011).

\section{CONCLUSION}

The qualitative analysis of 60 DNAs (57 rubber genotypes and three parent clones) produced highquality DNA. The DNA purity value ranged from 1.82.0, which classified as the absence of contaminants. The DNA fragments pattern shows the presence of polymorphism. The amplification results of the seven primers generated a total of 47 fragments with 1-13 fragments per primer. 13 DNA fragments were produced by OPA 02, whereas OPB 04 only one DNA fragments. The genetic similarity coefficients obtained ranged between $62-96 \%$. The highest genetic similarity (96\%) obtained from genotype 70 and 78 . Based on the genetic similarity matrix, it found that 42 of 57 rubber genotypes had the closest kinship relationship with PB 260 clones, and 6 of them had a vigorous growth response with the in vitro microcutting culture.

\section{REFERENCES}

Ausubel FM, Brent R, Kingston RE, Moore DD, Seidman JG, Smith JA, Struhl K, Ferreira AJ, Neidhardt FC, Ingraham JL, Schaechter M. 1999. Short protocols in molecular biology:a compendium of methods from current protocols in molecular biology. Piracicaba:Faculdade de Medicina Veterinária e Zootecnia.

Clément-DemangeA, Priyadarshan P, Thuy Hoa TT, Venkatachalam P. 2007. Hevea rubber breeding and genetics. Plant Breeding Reviews 29:177-283.

Demeke T, Adams RP. 1994. The use of PCR-RAPD Analysis in Plant Taxonomy and Evolution. London: CRC Press Inc.

Dijkman MJ. 1951. HEVEA:Thirty Years of Research in the Far East (No.678/D575). Coral Gables:University of Miami Pr.

Granet F, Lardet L, Leclercq J, Dessailly F, Martin F, Gaurel S, Uche E, Rio M, Oliver G, Montoro P, Carron MP. 2011. Development of new varietal types based on rejuvenation by somatic embryogenesis and propagation by conventional budding or micro cutting in Hevea brasiliensis. Acta Horticulturae 961:553-576.

[Kementan] Kementerian Pertanian. 2017. Outlook Karet Komoditas Pertanian Subsektor Perkebunan. Jakarta:Pusat Data dan Sistem Informasi Pertanian.

Martiansyah I, Eris DD, Nurhaimi H, Taniwiryono D. 2013. Optimasi prosedur sterilisasi permukaan eksplan stek mikro karet (Hevea brasiliensis Muell. Arg). Menara Perkebunan 81:9-14.
Mignon E, Werbrouck S. 2018. Somatic embryogenesis as key technology for shaping the rubber tree of the future. Frontiers in Plant Science 9:1804. DOI:10.3389/ fpls.2018.01804

Mondini L, Noorani A, Pagnotta MA. 2009. Assessing plant genetic diversity by molecular tools. Diversity 1:19-35.

Nejatzadeh-Barandozi F, Naghavi MR, Enferadi ST, Mousavi A, Mostofi Y, Hassani ME. 2012. Genetic diversity of accessions of Iranian Aloevera based on horticultural traits and RAPD markers. Industrial Crops and Products 37:347-351. DOI:10.1016/J.INDCROP.2011.12.013

Nurhaimi-Haris, Sumaryono, Carron MP. 2009. Pengaruh bahan pra-sterilan, tutup tabung kultur, dan musim terhadap tingkat kontaminasi eksplan pada kultur microcutting karet. Menara Perkebunan 77:89-99.

Nurhaimi-Haris, Hajrial A, Nurita TM, Agus P. 2003. Kemiripan genetic klon karet (Hevea brasiliensis Muell Arg.) berdasarkan metode amplified fragment length polymorphisms (AFLP). Menara Perkebunan 71:1-15.

Nurhaimi-Haris, S. Woelan, A. Darussamin. 1998. RAPD Genetics variability in plant rubber (Hevea brasiliensis Muell.Arg) clones. Menara Perkebunan 66:9-19.

Nurhaimi-Haris, Sumaryono, Siswanto, Martiansyah I, Sinta MM. 2011. Laporan akhir tahun kerja sama PTPN III dengan BPBPI di bidang penelitian dan perbanyakan in vitro komoditas karet. [Laporan Akhir Kegiatan 2010]. Bogor: Balai Penelitian Bioteknologi Perkebunan Indonesia.

Orozco-Castillo C, Chalmers KJ, Waugh R, Powell W. 1994. Detection of genetic diversity and selective gene introgression in coffee using RAPD markers. Theoretical and applied genetics 87:934-40.

Purwanto E, Sukaya E, Setianto, Santoso H. 2002. Identification based on isozymes marker on Citrus maxima Merr. in Blora Central Java. Bio SMART 4:44-47

RohlfFJ, Slice DE. 1993. Exeter Software. NTSYS-pc. Version. 1. Sambrook J, Russel DW. 1989. Molecular Cloning: A Laboratory Manual, 3 ed. New York: Cold-Spring Harbor Laboratory Pr.

Sharma R, Sharma S, Kumar S. 2018. Pair-wise combinations of RAPD primers for diversity analysis with reference to protein and single primer RAPD in soybean. Annals of Agrarian Science 16:243-249.

Siagian N. 2012. Pembibitan dan Pengadaan Bahan Tanam Karet Unggul. Medan:Balai Penelitian Sungei Putih.

Suryanto D. 2003. Melihat keanekaragaman organisme melalui beberapa teknik genetika molekuler. USU Digital Library [terhubung berkala]. Available at: http://www.library.usu. ac.id/modules.php [Date accessed: 7 Juni 2017]

Williams JG, Kubelik AR, Livak KJ, Rafalski JA, Tingey SV. 1990. DNA polymorphisms amplified by arbitrary primers are useful as genetic markers. Nucleic Acids Research 25 18:6531-6535.

Wilson PD, Wilson K, Walker J. 2000. Principles and Techniques of Practical Biochemistry. Cambridge:Cambridge University Press.

Yuwono T. 2006. Teori dan Aplikasi Polymerase Chain Reaction. Yogyakarta: Andi Offset. 